\title{
Shopping for Health: Beans, Peas, and Lentils ${ }^{1}$
}

\author{
Lakshmi Mahan, Lauren Foster, and Wendy J. Dahl ${ }^{2}$
}

\section{What's the Big Deal about Beans?}

Beans, one of the most wholesome foods in nature, provide a wide range of health benefits - they come packed with protein, fiber, and vitamins. Naturally low in fat, they contain no cholesterol and are very low in saturated fat. ${ }^{(1)}$ Beans rich in color are also high in antioxidants.

\section{Shopping for Beans}

Beans, peas, and lentils are also called legumes or pulses. A wide variety of legumes is found all over the world, each with a unique color, shape, and flavor. Some commonly consumed beans, peas, and lentils are featured throughout this publication.

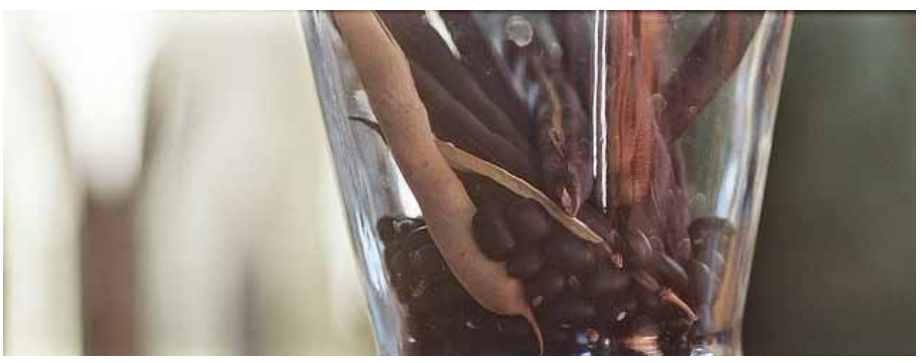

Figure 1. Black turtle

Credits: Photo by Sarah Gilbert, used here under Creative Commons license CC BY-NC-SA 2.0. Source: http://flic.kr/p/7j27P4.

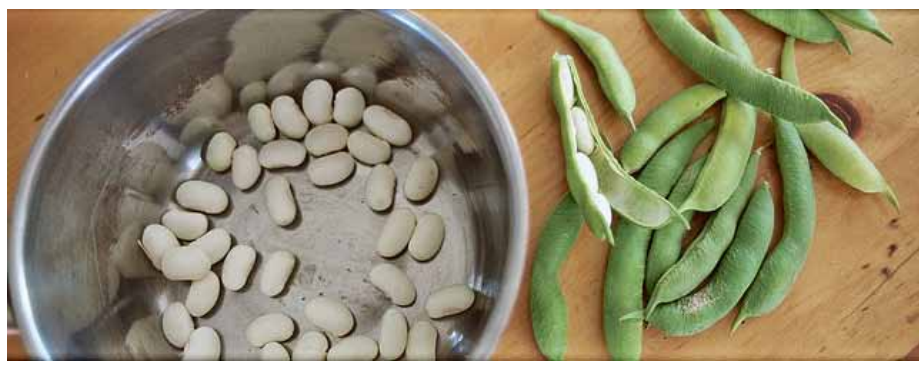

Figure 2. Cannellini

Credits: Photo by Sarah Gilbert, used here under Creative Commons license CC BY-NC-SA 2.0. Source: http://flic.kr/p/7kTEAc.

\section{Dried Beans}

When shopping for dried beans, you should look for beans that are bright in color and uniform in size. Do not purchase packages with cracked or broken beans, as they might have been damaged by insects.

\section{Canned Varieties}

Various types of beans come in a canned form, including red kidney beans, white kidney beans, pinto beans, black beans, and garbanzo beans / chickpeas. When choosing canned beans, those that are labeled "low sodium" or "no added salt" are the healthiest choices. For more information on reduced-sodium foods, see Shopping for Health: Sodium (EDIS \#FSHN10-06) at http://edis.ifas.ufl.edu/fs154.

Beans, peas, and lentils may be available fresh, frozen, or, more commonly, dried or canned.

1. This document is FSHN11-05, one of a series of the Food Science and Human Nutrition Department, Florida Cooperative Extension Service, Institute of Food and Agricultural Sciences, University of Florida. Published June 2011. Visit the EDIS website at http://edis.ifas.ufl.edu/.

2. Lakshmi Mahan, MS, Lauren Foster, BS, and Wendy J. Dahl, PhD, assistant professor; Food Science and Human Nutrition Department; University of Florida; Gainesville, FL 32611.

The use of trade names in this publication is solely for the purpose of providing specific information. UF/IFAS does not guarantee or warranty the products named, and reference to them in this publication does not signify our approval to the exclusion of other products of suitable composition. 


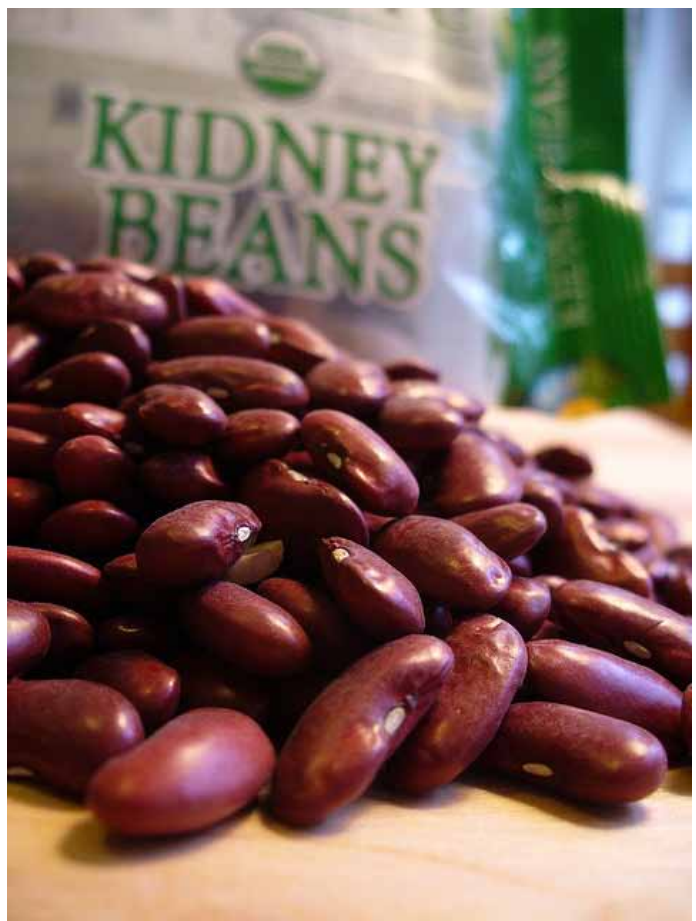

Figure 3. Red Kidney

Credits: Photo by $m t s n$, used here under Creative Commons license CC BY-NC 2.0. Source: http://flic.kr/p/q5c89.

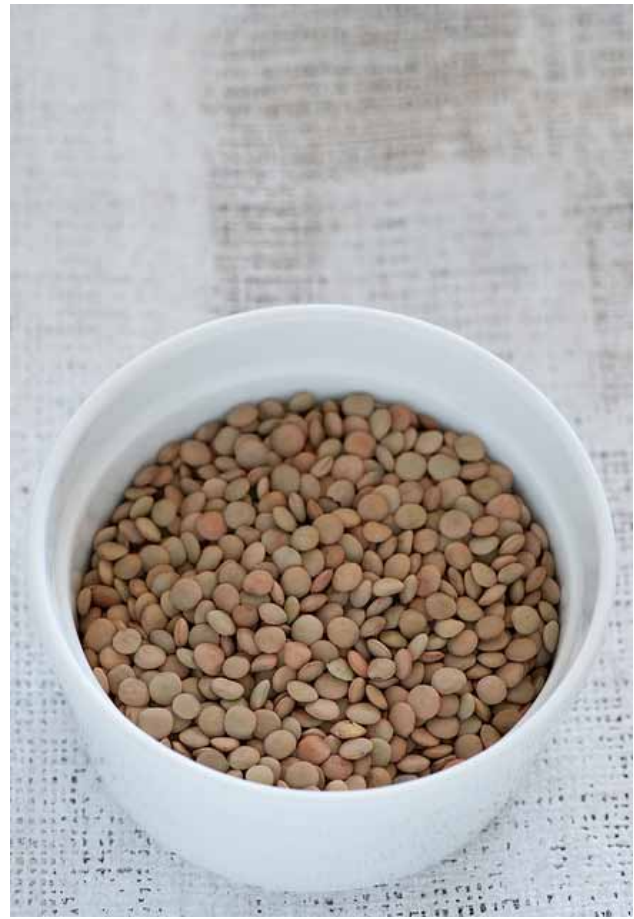

Figure 4. Brown Lentils

Credits: Photo by Jules Clancy / StoneSoup, used here under Creative Commons license CC BY 2.0. Source: http://flic.kr/p/8Cvxiw.

\section{Beans and Nutrition}

When deciding what type of beans to buy, consider nutritional content. Most beans have similar base nutritional values, being high in protein and fiber. Table $\mathbf{1}$ lists

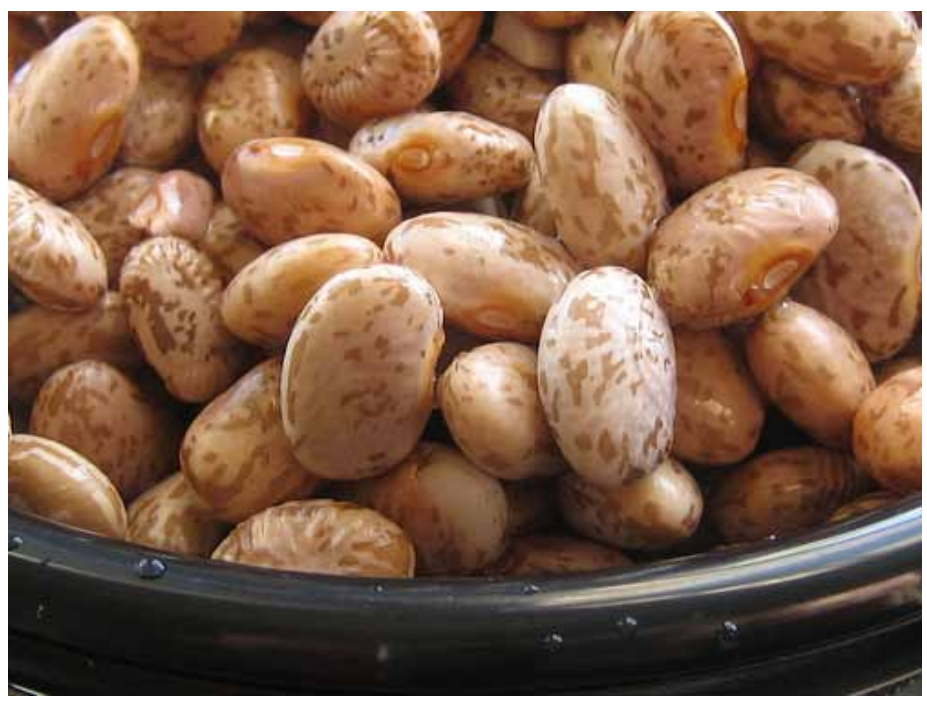

Figure 5. Pinto

Credits: Photo by nemka, used here under Creative Commons license CC BY-NC-SA 2.0. Source: http://flic.kr/p/7zqgDD.

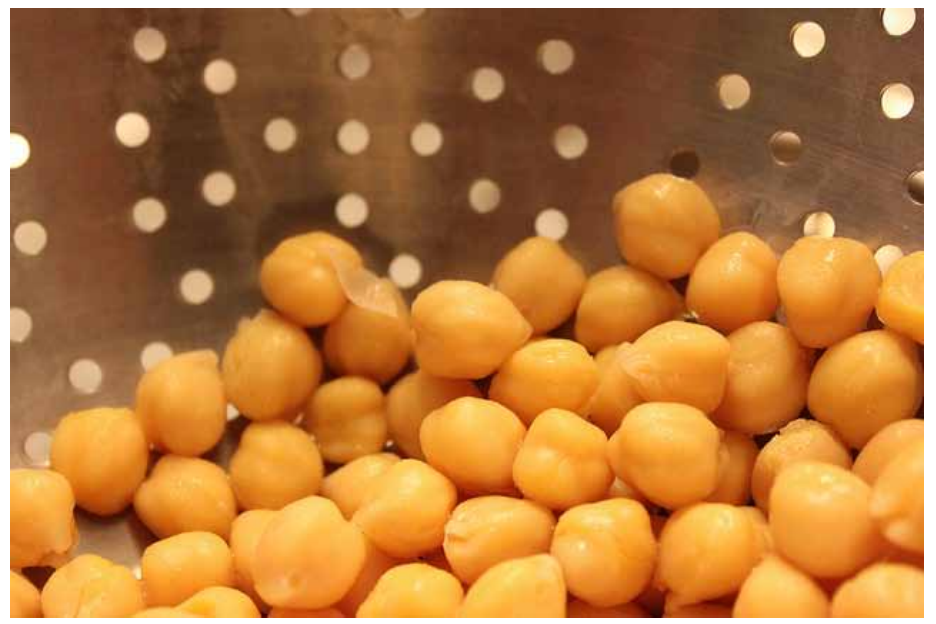

Figure 6. Chickpeas

Credits: Photo by Judith Doyle, used here under Creative Commons license CC BY-ND 2.0. Source: http://flic.kr/p/7RXtSC.

some common beans and their protein, fiber, and calorie contents. $^{(2)}$

\section{Meals with Beans}

Beans can be used in a variety of ways, from salad toppings to main course dishes. Table 2 lists some good ways to incorporate canned beans into different dishes. Beans can also be incorporated into desserts, snacks, and convenience foods. For example, canned kidney beans can be mashed and added to canned pasta and tomato sauce, or even used to extend ground beef in burgers and meatloaf. "Low sodium" or "no added salt" canned beans work very well in cake and cookie recipes. See what follows for some great recipes! 


\section{BLACK-BEAN BROWNIES}

1 box brownie mix (plus additional required ingredients listed on box)

1 can (15 ounce) black beans, no salt added, drained and rinsed

Mash black beans with a fork until very smooth. Prepare brownie mix, following directions on the box, and stir in mashed beans as last ingredient. Bake brownies according to box instructions. Enjoy!

\section{BIRTHDAY CUPCAKES}

1 box vanilla cake mix (plus additional required ingredients listed on box)

1 (15 ounce) can cannellini beans, no salt added

Mash beans in a separate bowl with a fork until smooth. Prepare cake mix, following directions on the box, adding beans with other required ingredients. Mix well. Bake according to directions. Frost with choice of frosting.

\section{CREAMY BLACK-BEAN DIP}

1 container (16 ounce) fat-free cream cheese

1 can (15 ounce) reduced-sodium black beans, drained and rinsed

3 Tbsp fresh cilantro

2 Tbsp chopped tomato (optional)

$3 / 4$ cup cheddar cheese, shredded

Salt and pepper to taste

Mash half the can of beans with a fork. Mix mashed beans with the cream cheese and cilantro until smooth. Gently stir in the rest of the beans. Before serving, sprinkle cheese and chopped tomato on top. Serve with tortilla chips or crackers.

\section{Learn More}

The Family and Consumer Sciences (FCS) agent at your county Extension office may have more information. In Florida, visit http://solutionsforyourlife.ufl.edu/map/ to find your local county Extension office.

More bean recipes can be found at:

http://www.usdrybeans.com/

http://archive.saskpulse.com/consumer/ [19 October 2012]

http://www.pulsecanada.com/recipes
Reliable nutrition information may be found at the following sites:

http://fycs.ifas.ufl.edu

http://solutionsforyourlife.ufl.edu

http://www.nutrition.gov

http://www.nal.usda.gov/nal_display/index/php?info_ center=4\&tax_level $=1$ [September 2011]

\section{Endnotes}

(1) U.S. Department of Agriculture. Inside the pyramid: Dry beans and peas in the food guide. 11 Sep 2008. Web. http:// www.mypyramid.gov/pyramid/meat_beans_print.html.

(2) U.S. Department of Agriculture, Agricultural Research Service. 2009. National Nutrient Database for Standard Reference, Release 22. Nutrient Data Laboratory Home Page, http://www.ars.usda.gov/ba/bhnrc/ndl. 
Table 1. Protein and fiber contents of beans with average calorie counts per serving

\begin{tabular}{|c|c|c|c|}
\hline Beans ( $1 / 2$ cup serving) & Calories & Protein (g) & Fiber (g) \\
\hline Red Kidney & 110 & 7 & 6 \\
\hline Pinto & 120 & 8 & 7 \\
\hline Black (Turtle) & 120 & 7 & 5 \\
\hline Chickpeas & 140 & 7 & 6 \\
\hline Green Peas & 60 & 4 & 3 \\
\hline Lentils & 110 & 9 & 8 \\
\hline
\end{tabular}

Table 2. Adding beans to your meals

\begin{tabular}{|l|l|}
\hline Bean Type & Use \\
\hline Navy & Soups, stews, baked beans, purées \\
\hline Kidney & Chili, three-bean salads \\
\hline Pinto & Refried, stews, dips, Tex-Mex dishes \\
\hline Great Northern & Soups, stews \\
\hline Garbanzo & Salads, hummus \\
\hline Lentils & Soups, stews \\
\hline
\end{tabular}

